\title{
The Reconstructive Options for Lower Extremity Defects: 10-Year Retrospective Study
}

\author{
• Çağla Çiçek, • Mustafa Erol Demirseren²
}

\section{'Department of Reconstructive and Aesthetic Surgery, University of Health Sciences, Kartal Dr. Lütfi Kırdar Training and Research Hospital, İstanbul, Turkey ${ }^{2}$ Department of Reconstructive and Aesthetic Surgery, Yıldııım Beyazıt University Bilkent City Hospital, Ankara, Turkey \\ Submitted: 24.04.2019 Accepted: 12.06.2019 \\ Correspondence: Çağla Çiçek Sağlık Bilimleri Üniversitesi, Kartal Dr. Lütfi Kırdar Eğitim ve \\ Araştırma Hastanesi Plastik \\ Rekonstrüktif ve Estetik Cerrahi Kliniği, İstanbul, Turkey E-mail: \\ caglamutkan2002@yahoo.com}

Keywords: Free flap; lower
extremity; reconstruction.
Attribution-NonCommercial 4.0 International License.

\begin{abstract}
Objective: Complications, functional and aesthetical results of patients, what kind of reconstructive methods were preferred, diversity in the surgical techniques which are preferred within years, advantages and disadvantages of different techniques with respect to each, were evaluated in patients who were operated in our clinic to determine our experience in the lower extremity soft tissue repair.
\end{abstract}

Methods: The techniques which are used for the reconstruction of 1017 soft tissue defects of the lower extremity, were evaluated retrospectively in between January 2004 and August 2017. According to archive scan results, patients' age, gender, the etiology of the lower extremity defects, defect localization, the selected surgical method for closure of the defect, complications, the number of surgeries were determined.

Results: In our study, 873 patients were included and 1017 defects were operated. Of patients $69.99 \%(n=61 \mathrm{I})$ were male, $30.01 \%$ of them $(n=262)$ were female. The average age was 46.2 (7-85) years and it was evaluated that the most common etiologic cause was trauma. The feet were the predominantly affected sites among the defect areas. Graft application was the most preferred method of reconstruction among other methods for lower extremity tissue defects.

Conclusion: The lower steps of the reconstructive ladder for the lower extremity reconstruction, are more preferred over the past 30 years. Despite all the surgical developments, it should not be forgotten that the amputation might be inevitable and the methods preferred may not provide the best results in the long term when lower extremity function is considered.

\section{INTRODUCTION}

When the historical development of plastic surgery is studied, it is observed that methods for tissue loss have been defined. For this reason, although there have been many popular methods in soft tissue reconstruction recently, surgical planning appropriate for reconstruction is especially important. Some specific features of lower extremity must be kept in mind in reconstruction. ${ }^{[1]}$ When the etiology of these defects is studied, it is seen that they mainly form as a result of car accidents, falling down from a high place, being wounded by fire-arms or plate-screw exposition, osteomyelitis or a result of tumour excision. ${ }^{[2]}$ The presence of bones, tendons or neurovascular structures under the defect and the exposition of rigid fixation materials make these tissue defects more complicated. Microvascular free tissue transplant have recently become widespread in the reconstruction of lower extremity soft tissue defects so conservative treatments for the extremity that was formerly amputation decision are at the forefront. The reconstruction of soft tissue defects in the lower extremity is still controversial regardless of the cause, and may result in the patient's having more than one operation. The rehabilitation of the patient takes long time. For this reason, to transfer our experience on the reconstruction of lower extremity defects, the aim is to present an up-to-date approach based on our experience in our clinic and the recently developed techniques in the literature.

\section{MATERIALS AND METHODS}

In this study, the patients who were operated for lower extremity soft tissue defects were studied by analyzing op- 
eration logs and patient files retrospectively. As a result of the archive analyzing, the age, gender, etiology of lower extremity soft tissue defects, the site of the defect, the method used for coverage, complications, and the number of operations were found out.

\section{Statistical analysis}

IBM SPSS Statistics 2I.0 (IBM Corp. Released 20I2.IBM SPSS Statistics for Windows, Version 2 I.0.Armonk,NY:IBM Corp.) and MS. Excel 2007 were used for the statistical analysis and calculations.

\section{RESULTS}

In this study, as a result of the archive analyzing it was found out that a total of 873 patients with an average age of 46.2 (7-85) years and an age median of 46.00 years were operated on. $69.99 \%(n=6 I I)$ of the patients are males and $30.01(n=262)$ are females. The average followup of the patients are 7 years 10 months $(6$ months- 13 years). When the etiological causes of the patients with lower extremity soft tissue defects are studied, it is seen that the most frequent factor is tissue defects caused by trauma. The second most frequent etiological cause is secondary tissue defects related to diabetes, arterial insufficiency and venous ulcers. This is followed by complications related to various operations. 102 patients whose etiological causes were post-operative complications were operated by orthopaedics or cardio-vascular surgeons and were consulted to our clinic due to infection in the defect area, suture dehiscence or lower extremity open wound secondary to osteomyelitis. Other causes are defects formed after abscess drainage, soft tissue defects caused by hematoma related to Coumadin use, fasciotomy defects and the reconstruction of tissue defects caused by lymphedema surgery (Table I). The interval between operation and tissue defect formation is 17 days on average ( 24 hours -4 weeks). A total of 873 patients were examined in our study and reconstruction was conducted for the coverage of 1017 defects. The reason for the patients' having more than one operation is the second session of flaps applied as interpolation, complications and revisions. The negative pressure wound coverage practices in the operation room and debridements are excluded in the study. Thirthy-one of the patients had tissue defects in more than one area in a maximum of three anatomic regions and the average number of defects was studied as 1.03 . When the defects of the patients in the study is examined, it is seen that the most frequent defect is on the foot whereas the second most frequent defect is on the leg. When the surgery methods used for the reconstruction of the defects of the patients included in the study are studied, grafts was applied to $36.0 \%(n=367)$ of the patients. The defects of $4.12 \%(n=42)$ of the patients had primary reconstruction whereas the defect of $36.0 \%$ $(n=367)$ of the patients were left open for secondary reconstruction. Besides $0.78 \%(n=8)$ of the patients' defects were reconstructed with adipofacial flap, $16.12 \%(n=164)$ with fasciocutaneous flap, $6.29 \%(n=64)$ of the patient defects with muscle flap, $2.85 \%(n=29)$ of the patient defects with perforator and $0.39(n=4)$ with free flap. $19.37 \%$ $(n=197)$ of the patients in the study underwent amputation in different levels (Table 2). The forty patients were operated for the complications following reconstructive surgery and revisions.

\section{DISCUSSION}

Trauma is the most frequent cause of tissue defects in the lower extremity and the treatment of soft tissue and bone injuries formed in the extremity following trauma is still a

Table I. Etiology of lower extremity soft tissue defects

\section{Clinical findings $(n=1017)$}

Defect etiology

Trauma

Peripheric vascular disease

(Venous ulcer, diabetic foot, burger disease, peripheric artery disease)

Postoperative complications (Cardiovascular/tissue defect following

orthopaedic surgery)

Tumour excision

Burn/burn contracture release

Falling from height

Decubitus ulcer (İskiyal/Trochanteric and heel decubitus ulcer)

Necrotizing fasciitis

Others (Apsis, necrosis induced by hematoma related to Coumadin use,

Fasciotomy defect, Lenf oedema surgery)

Total
Traffic accidents 256 (29.32)

Industrial accidents 107 (12.25)

Fire-arin injury 68 (7.78)
43I (49.36)

20 (2.29)

II (I.26)

$21(2.40)$

$873(100.00)$ 
Table 2. Surgical method for lower extremity recontruction

\begin{tabular}{|c|c|}
\hline Surgical method & $\mathbf{n}$ \\
\hline Primary wound healing & 42 \\
\hline Secondary wound healing & 142 \\
\hline Split thickness skin graft & 358 \\
\hline Full thickness skin graft & 9 \\
\hline Facial/adipofacial flap & 8 \\
\hline Reverse sural flap & 54 \\
\hline Reverse ALT & 4 \\
\hline Lateral calcaneal flap & 2 \\
\hline Medial calcaneal flap & I \\
\hline Cross leg reverse sural flap & 19 \\
\hline Transposition flap & 5 \\
\hline \multicolumn{2}{|l|}{ Fasciacutaneous flaps } \\
\hline Rotation flap & 13 \\
\hline Bipediculed flap & 14 \\
\hline Rotation advancement (hatched) flap & 3 \\
\hline Advancement flap & 17 \\
\hline V-Y advancement flap & 9 \\
\hline Bilobed flap & 3 \\
\hline Double-S plasty & 8 \\
\hline Z-plasty & 12 \\
\hline Gastrocinemius muscle flap & 23 \\
\hline Soleus/hemisoleus muscle flap & I \\
\hline Biceps femoris muscle flap & 6 \\
\hline \multicolumn{2}{|l|}{ Muscle/muscle-skin flap } \\
\hline Tensor facia lata muscle flap & 9 \\
\hline Gracilis muscle flap & 1 \\
\hline Vastus lateralis muscle flap & 1 \\
\hline Peroneus brevis muscle flap & 17 \\
\hline Cross leg gastrocinemius muscle flap & 6 \\
\hline Posterior tibial artery PF (PTAPF) & 8 \\
\hline Cross leg PTAPF & I \\
\hline Peroneal artery PF & 2 \\
\hline \multicolumn{2}{|l|}{ Perforator flap (PF) } \\
\hline Medial genicular artery PF & 2 \\
\hline Lateral genicular artery PF & I \\
\hline Medial plantar artery PF & 6 \\
\hline Anterolateral thigh flap (ALT) & 9 \\
\hline \multicolumn{2}{|l|}{ Free flap } \\
\hline ALT flap & 1 \\
\hline Lattisimus dorsi flap & 3 \\
\hline Amputation & 197 \\
\hline Total & 1017 \\
\hline
\end{tabular}

widely discussed and challenging topic. ${ }^{[3]}$ Thus, the treatment of these injuries requires a multidisciplinary approach which includes the evaluation of bone defects, soft tissue injury and neurovascular structures, and the rehabilitation of the patient. ${ }^{[4]}$ Primary reconstruction may be considered for mainly thigh and proximal $2 / 3$ defects of leg if the defect is not large and in tension. ${ }^{[5,6]}$ Tissue defects which are small in size and in which bones, tendons and neu- rovascular structures are not exposed may be left open for secondary recovery. Due to the presence of thick soft tissue covering bony surfaces on the thigh and proximal $2 / 3$ of leg, bones and vital neurovascular structures are usually not exposed here. ${ }^{[7]}$ For this reason, grafting is the most frequently used method in the reconstruction of these regions. Similarly, in our clinic reconstruction with grafts was widely preferred for thigh, knee, proximal 2/3 of leg and foot dorsum defects. Local flaps which are planned as fasciocutaneous, play an important role in lower extremity reconstruction as they can be applied locally to small defects which are not suitable for graft, and as they do not impair muscle function. ${ }^{[3,8,9]}$ Similarly, 84 local random fasciocutaneous flaps were preferred in our clinic for lower extremity reconstruction. ${ }^{[10]}$ The defects concerning knee may be seen as complicated defects where the knee joint and the metal instrument may be exposed. In our study, the reconstruction of 54 knee area defects were analysed and graft was preferred in 23 cases. Any bone, vessel and plate-screw are not exposed in any of the defects in these patients. Local fasciocutaneous flaps, perforator flaps and muscle flaps are suitable and reliable flaps for the reconstruction of this area in complicated cases. Reverse anterolateral thigh flap is the first among the perforator flaps which can be preferred. Reverse flow anterolateral thigh flaps have significant advantages such as being more reliable than random local flaps, not requiring anastomosis even if microsurgical dissection is necessary, and providing the most similar tissue for the defect in terms of colour and structure. Reverse flow anterolateral thigh flap was applied to 3 patients for the knee area. None of the patients experienced venous congestion contrary to what is stated in literature. Gastrocnemius and tibialis anterior muscle flaps are among the options that can be used as muscle flaps. ${ }^{\left[{ }^{11]}\right]}$ In our study, 5 gastrocnemius muscle flap medial heads were used for the knee area. Only I patient developed near total muscle necrosis. Free flap was not used in our clinic for any patient for the reconstruction of this area. The soft tissue in proximal I/3 of leg is a thicker anatomic area compared to the other areas of the leg, and can be reconstructed similar to the defects of the knee. ${ }^{[12]}$ In our study, grafting was most frequently used for the reconstruction of this area. This is followed by gastrocnemius muscle flap. Local random fasciocutaneous flaps were also used successfully in our clinic for the reconstruction of this area. The use of muscle and fasciocutaneous flaps are suggested for the reconstruction of proximal I/3 of leg defects. The first option to be used as muscle flap is proximal or distal based soleus/hemisoleus muscle flap. Saleh et al. ${ }^{[3]}$ have stated that the dissection of the soleus muscle proximal is difficult. In addition, they have stated that distal based soleus flaps are not reliable enough as one cannot be sure of the location and dimension of pedicles in the distal. In our study, graft was the most frequently used surgery method with 97 patients who underwent surgery for proximal I/3 of leg defects. Local random faciocutaneous flap was applied to 4 patients and no complications were experienced. Soleus flap was used for one patient. 
Gastrocnemius muscle flaps from the same or the opposite side were used in 10 patients. One patient had free anterolateral thigh flap and no complications occurred. The majority of the studies and discussions in the literature is about the coverage of defects of the foot and distal part of leg, and the concept have evolved throughout the years. As muscles get thinner and tendons become superficial beyond the tibia distal, there is no muscle tissue that has distinct bulks mass. In addition, due to the thinning of soft tissue on the neurovascular structures and bone spur (medial and lateral malleols) it becomes more superficial. As limited tissue can be obtained by proximal based fasciocutaneous flaps, reverse flow flaps were mainly preferred for this area. The most frequently used flap is reverse flow sural flap. The advantages are the practicality of planning and usage, easiness of teaching to use it, fixed vascular pattern, reliability, and not having the need for the dissection of a major artery or nerve. ${ }^{[13]}$ As in all reverse flow flaps, there may be circulation problems. In addition, the need for a pivot point 5-7 centimetres above lateral malleol, shortness of rotation arch due to this, and mass look in the pivot point, and the covering of the pedicle with graft are other advantages. ${ }^{[14]}$ Bauemeister et al. ${ }^{[15]}$ stated that the rate of complication in a total of 70 cases was $59 \%$, and the partial or total flap loss as $39 \%$. In our study,a total of 20 reverse flow sural flaps were used from the same or the opposite leg for distal I/3 of leg defects. Hematoma developed in I flap planned as cross reverse flow; the flap was put back in its own place following the evacuation of hematoma. Partial necrosis developed in flap distal in 2 patients for whom the same leg was planned. These rates are much below the complication rates stated in literature. Parrett et al. ${ }^{[2]}$ have argued that fasciocutaneous and perforator flaps should be used more than free flaps in distal I/3 defects of the leg as they can be removed in fast, easy and single stage dissection and does not require the dissection of the main arteries of the leg in addition to shorter surgery duration. In our study, perforator flap was used for 4 patients for the defects of this area. Another flap option that can be used for the reconstruction of lateral malleol tissue defects is pereneus brevis muscle flap. Short surgery time, provision of reliable soft tissue cover and low morbidity of donor site are the most significant advantages. ${ }^{[15]}$ This type of flap was used for 17 patients and none of the patients had complications. Dorsalis pedis based 'turn over' flaps were especially used in our clinic for leg distal I/3 anterior defects. Only 2 patients had free latisimus dorsi muscle skin flap for this area. Local fasciocutaneous and perforator flaps are used more frequently than free flaps for this area in the literature..$^{[2,16]}$ In our study, graft was the most frequently preferred method for the reconstruction of distal I/3 of leg defects. Bones or plate-screw are not exposed in any of the defects suitable for graft. As stated above, reverse flow sural flap from the same or the opposite leg had the second most frequent use for this area. The ankle is a mobile transition area between the sole and the leg where all the functions of the leg are transferred to the foot. The flaps that can be used for this area are latissimus dorsi and rectus abdominis muscle flaps. Their anatomy and the stability of vascular pedicles increase their convenience. Although the success rates of free flaps have increased over the years, the aesthetic results of these flaps are generally not as desired because even a long time after application, muscle flaps usually remain thick and do not get thinner as assumed. Although free flaps are routine applications in the covering of lower extremity defects, the failure rates of the flaps are as high as $20 \%$ in some publications. ${ }^{[17]}$ Another issue related to the application of free flaps is how successful these flaps can be as the age increases. Dumont et al. found out in their study that patients over 60 who underwent lower extremity reconstruction with local pedicle flaps had higher rates of post-operative complications and flap flow problems compared to free flaps. However, general mortality and morbidity were lower than free flaps. ${ }^{[18]}$ In our study, latissimus dorsi free flap was performed on one patient for foot dorsum and total necrosis developed. For this reason, the defect of the patient was covered with reverse flow sural flap planned as double stage. As a result, although free flaps have high success rates in the hands of experienced doctors, and allow for reliable coverage in defects where large and different tissues are needed, they also have disadvantages such as long duration of surgery, need for experience in microsurgery and being expensive.

\section{CONCLUSION}

The main cause of soft tissue defects in the lower extremity is trauma caused by car accidents. The reconstruction of the soft tissue may become difficult due to close proximity to bones, arteries and nerves. So, there are many studies and discussions on the reconstruction methods of this area. The main aim for the treatment of the patient is ensuring immediate aesthetic and functional results and performing the treatment method that will result in minimum morbidity. The methods that will be used in the reconstruction of soft tissue defects depends on the site and size of the defect, the presence of exposed vital anatomic structures, the viability of the surrounding tissue, the general state and expectations of the patient. A great number of extremities did not require amputation due to the improvement in wound care methods, anatomic studies on vascularisation of the extremity, and microsurgery methods in the last 30 years. However, following the second half of these 30 years, lower steps of the reconstructive ladder are more frequently used. That is, it is seen that the use of free flap decreases whereas the use of local flap increases. However, it should be kept in mind that solutions used to maintain function may not give the best results in the long term and amputation may sometimes be unavoidable for the patient.

\section{Ethics Committee Approval}

Due to retrospective nature of this study no ethic committee approval was taken. 


\section{Informed Consent}

\section{Retrospective study.}

Peer-review

Internally peer-reviewed.

Authorship Contributions

Concept: C.C.; Design: C.C.; Data: C.C.; Analysis: C.C.; Literature search: C.C.; Writing: C.C.; Critical revision: C.C., M.E.D.

Conflict of Interest

None declared.

\section{REFERENCES}

1. Thorne CH. Grabb and Smith's Plastic Surgery (6th ed). Philadelphia: Lippincott Williams and Wilkins; 2007. p. 676-88.

2. Parrett BM, Pribaz JJ. Lower extremity reconstruction. Rev Med Clin Condes 2010;21:66-75.

3. Saleh Y, Wahebb B, Abd-Elaziz MA, El-Oteify M. A suggested algorithm for post-traumatic lower limb soft tissue reconstruction. Egypt J Plast Reconstr Surg 2007;1:87-96.

4. Medina ND, Kovach SJ, Levin LS. An evidence-based approach to lower extremity acute trauma. Plast Reconstr Surg 2011;127:926-31.

5. Roberts CS, Pape HC, Jones AL, Malkani AL, Rodriguez JL, Giannoudis PV. Damage control orthopaedics: evolving concepts in the treatment of patients who have sustained orthopaedic trauma. Instr Course Lect 2005;54:447-62. [CrossRef]

6. Rajasekaran S, Naresh Babu J, Dheenadhayalan J, Shetty AP, Sundararajan SR, Kumar M, et al. A score for predicting salvage and outcome in Gustilo type-IIIA and type-IIIB open tibial fractures.J Bone
Joint Surg Br. 2006;88:1351-60. [CrossRef]

7. McAndrew MP, Lantz BA. Initial care of massively traumatized lower extremities. Clin Orthop Relat Res 1989;20-9. [CrossRef]

8. Daecke W, Marzi I, Frank J. Reconstruction of lower extremity fractures with soft tissue defects. Eur J Trauma Emerg Surg 2007;33:24-32.

9. Griffin M, Malahias M, Khan W, Hindocha S. Update on the management of open lower limb fractures. Open Orthop J 2012;6:571-7.

10. Cole JD, Ansel LJ, Schwartzberg R. A sequential protocol for management of severe open tibial fractures. Clin Orthop Relat Res 1995;84-103. [CrossRef]

11. Zhang G. Reversed anterolateral thigh island flap and myocutaneous flap transplantation. Chin Med J 1990;70:676-8 (in Chinese).

12. Hollenbeck ST, Toranto JD, Taylor BJ, Ho TQ, Zenn MR, Erdmann $D$, et al. Perineal and lower extremity reconstruction. Plast Reconstr Surg 2011;128:551e-63e. [CrossRef]

13. Donski PK, Fogdestam I. Distally based fasciocutaneous flap from the sural region. A preliminary report. Scand J Plast Reconstr Surg 1983;17:191-6. [CrossRef]

14. Ruan HJ, Cai PH, Schleich AR, Fan CY, Chai YM. The extended peroneal artery perforator flap for lower extremity reconstruction. Ann Plast Surg 2010;64:451-7. [CrossRef]

15. Baumeister SP, Spierer R, Erdmann D, Sweis R, Levin LS, Germann GK. A realistic complication analysis of 70 sural artery flaps in a multimorbid patient group. Plast Reconstr Surg 2003;112:129-40. [CrossRef]

16. Ceran C, Demirseren ME, Aksam E, Cicek C, Demiralp CO. Lateral malleolar region defects with exposed implants: proximally based peroneus brevis muscle flap. J Wound Care 2015;24:372-7. [CrossRef]

17. Hallock GG. Evidence-based medicine: lower extremity acute trauma. Plast Reconstr Surg 2013;132:1733-41. [CrossRef]

18. Pu LL, Medalie DA, Rosenblum WJ, Lawrence SJ, Vasconez HC. Free tissue transfer to a difficult wound of the lower extremity. Ann Plast Surg 2004;53:222-8. [CrossRef]

\section{Alt Ekstremite Defektlerinin Kapatılmasında Rekonstrüktif Seçenekler: 10 Yıllık Geriye Dönük Çalışma}

Amaç: Alt ekstremite yumuşak doku onarımındaki deneyimlerimizi aktarmak amacıyla, kliniğimizde ameliyat edilen hastalarda tercih edilen kapatım yöntemleri, yıllar içerisinde seçilen cerrahi tekniklerdeki değişimler, farklı tekniklerin birbirlerine göre üstünlükleri, komplikasyonları, hastaların fonksiyonel ve estetik açıdan sonuçlarının ortaya konması amaçlanmışır.

Gereç ve Yöntem: Ocak 2004 ve Ağustos 2017 tarihleri arasında alt ekstremitede oluşan 1017 yumuşak doku defektlerinin rekonstrüksiyonunda kullanılan yöntemler geriye dönük olarak değerlendirildi. Arşiv taraması sonucunda hastaların yaşı, cinsiyetı, alt ekstremite açık yarasının etiyolojisi, defektin yerleşim yeri, defekt kapatımında seçilen yöntem, komplikasyon ve geçirilen ameliyat sayısı belirlendi.

Bulgular: Çalışmamıza 873 hasta dahil edilmiş ve 1017 defektin ameliyat edildiği tespit edilmiştir. Hastaların \%69.99'u ( $n=611)$ erkek, \%30.0l'i ( $n=262)$ kadın olarak saptanmıştır. Ortalama yaş 46.2 (7-85) ve en sık etiyolojik neden travma olarak değerlendirilmiştir. Defekt alanları incelendiğinde en sık ayakta doku defekti nedeniyle hastaların opere edildiği görülmüştür. Tüm alt ekstremite doku defektlerinin rekonstrüksiyonunda kullanılan cerrahi yönteme bakıldığında greftin tercih edildiği tespit edilmiştir.

Sonuç: Geçtiğimiz 30 yıl içerisinde alt esktremite rekonstrüksiyonunda rekonstrüktif merdivende alt basamaklara daha çok başvurulmuştur. Tüm bu gelişmelere rağmen fonksiyonu korumak için uygulanan çözümlerin uzun dönemde en iyi sonucu veremeyebileceği ve amputasyonun hasta için nadir de olsa kaçınılmaz olabileceği unutulmamalıdır.

Anahtar Sözcükler: Alt ekstremite; rekonstrüksiyon; serbest flep. 